França sob a forma de departamentos, com as modificações e adaptações exigidas pela situação.

O autor adverte no prefácio que entende por secularização não só a passagem efetiva das propriedades e instituiçōes para o Estado, mas também a supressão do usufruto, ou o emprêgo das mesmas para fins profanos.

A secularização assim entendida, atingiu profundamente a vida da igreja católica da Alemanha, até então a maior do Ocidente.

Sob a denominação de "instituições espirituais de Colônia", devem ser entendidas as igrejas paroquiais e das ordens, as abadias, mosteiros, as fundações, e até o seminário sacerdotal, situados no território sob jurisdição da cidade de Colônia, com tôdas as consequiências sociais e econômicas daí decorrentes.

$\mathrm{Na}$ primeira parte do volume, o autor analisa os fundamentos econômicos, sociais e geográficos da região, estudando a cidade de Colônia sob os mais diferentes aspectos (situação geográfica, povoamento, administração, comércio e agricultura). Para dar um sentido comparativo ao seu estudo, é analisado também o Departamento do Rur, desmembrado de Colônia em 1798, focalizando a estrutura topográfica e administrativa da região.

A segunda parte da obra se ocupa com a preparação e o desfecho da secularização em si. São arroladas as medidas restritivas que a propriedade já vinha sofrendo e que culminaram na secularização formal de 1802, depois da total incorporação da regiăo à França, dividida em quatro departamentos com sede em Mogúncia.

Na terceira e última parte do volume, o autor se estende na análise das conseqüências econômicas e sociais geradas pela transferência das vastas propriedadcs eclesiásticas secularizadas para o domínio civil, bem como na legislação pròpriamente dita que presidiu a esta transferência. Anota que as instituiçóos eclesiásticas perderam, em Colônia, cêrca de 37 mil hectares de terra. As instituições espirituais ocupavam $50 \%$ da cidade de Colônia, intra-muros, e arrecadavam o dôbro da própria administração civil urbana. A transferência para a sociedade laica das mesmas, produziu mudanças econômicas e sociais profundas, e conduziu a um rápido desenvolvimento comercial da região situada na margem esquerda do Reno.

OSWALDO SCHULER.

PALACIN (Luíz). - Goiás, 1722-1822: estrutura e conjuntura numa capitania de minas. Edição do Departamento Estadual de Cultura de Goiás. Instituto Goiano do Livro. 1972. $182 \mathrm{pp.}$ 
O govêrno goiano acaba de divulgar a tese de livre-docência com que o Professor Luís Palacin, ilustre cultor da história dêsse Estado mediterrâneo se apresentou ao julgamento dos críticos. E uma preciosa contribuição ao estudo de um determinado período da vida goiana, desde o instante em que aí se instalou a mineração e se formou a sociedade que passou a viver, inicialmente, dessa atividade.

Em sete bem documentados capítulos o autor analisa a formação dos primeiros núcleos de povoamento e a "implantação das estruturas administrativas" que os deveriam reger. Depois, passa a analisar tudo aquilo que foi comum ao ciclo da mineração: o contrabando, os rios que produziam o metal e os diamantes, a fase do apogeu, para culminar, mais adiante, na análise do período da decadência. Passa em revista a formação étnica da região, assinalando as funções que tocavam a cada grupo. E é meticulosa, também, a análise que nos oferece dos aspectos da administração, examinando a obra dos governadores, da Justiça, da Fazenda Real e do Exército. O livro se encerra com a fase da decadência, com observações sôbre as comunicações, a agricultura e o comércio, naquele entrelaçamento natural que caracteriza essa tríade de atividade humanas.

Digno de registro é a citação das fontes "manuscritas" da História de Goiás, tecendo comentários sôbre a sua localização, parte na velha capital e parte na nova. A cada capítulo o cuidadoso pesquisador anexa valiosa série de notas, devidamente numeradas porque relacionadas com o texto, o que facilita o esfôrço do leitor.

Não pode ser esquecida a parte final da obra em tela, no que se refere aos quadros estatísticos e até mesmo gráficos, ilustrando os assuntos que vinha fundamentando em palavras. Estes ajudam ràpidamente a visão dos tópicos que vai expondo. A capa é reprodução do mapa de Colombina, elaborado talvez lá por 1751. Assinala, além dos limites da capitania, os caminhos e as localidades já existentes.

A historiografia de Goiás está verdadeiramente de parabens, pois o nôvo livro supera tudo o que já foi feito, dado que não se limita àquela costumeira análise dos fatos simplesmente, mas os focaliza no que êles têm de durável (a estrutura) e no que têm de transitório (a conjuntura). Está, pois, aberto o caminho da renovação para a boa interpretação da história de Goiás.

\section{HLITON FEDERICI.}

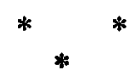

MELlo (Antônio de Oliveira). - Patos de Minas: capital do milho. Edição da Academia Patense de Letras. Patos. 1971. $350 \mathrm{pp}$. 